\title{
Clostridium saccharolyticum sp. nov., a Saccharolytic Species from Sewage Sludge $\dagger$
}

\author{
WILLIAM D. MURRAY, A. W. KHAN, AND L. VAN DEN BERG \\ Division of Biological Sciences, National Research Council of Canada, Ottawa, Canada KlA OR6
}

\begin{abstract}
A new species of Clostridium isolated from a methanogenic cellulose-enrichment culture of sewage sludge is described. The colonies produced by these bacteria were white, circular, and convex with smooth margins. The cells were straight, spindle-shaped rods, 0.6 by $3.0 \mu \mathrm{m}$ in size. They were gram negative and nonmotile, and they formed round, terminal spores. A wide variety of carbohydrates was fermented by this mesophilic anaerobe. The major fermentation products were acetic acid, hydrogen, carbon dioxide, and ethanol. The deoxyribonucleic acid base composition was $28 \mathrm{~mol} \%$ guanine plus cytosine. The name Clostridium saccharolyticum is proposed for this new species on the basis of its broad saccharolytic activity. The type strain of $C$. saccharolyticum is WM1 $(=$ NRC 2533).
\end{abstract}

A new species belonging to the genus Clostridium was isolated during the course of a study of the digestion of cellulose by a highly cellulolytic mixed culture. This culture was obtained from a methanogenic cellulose-enrichment culture started from sewage sludge $(4,5)$. In the present paper we define the characteristics of and propose a name for this newly discovered microorganism.

\section{MATERIALS AND METHODS}

Media. The basal medium used for the isolation and maintenance of the new isolate was the synthetic saltvitamin medium previously described by Khan et al. (6). The basal medium was supplemented with $0.1 \%$ yeast extract and was prepared by the procedure of Holdeman and Moore (1). The $\mathrm{pH}$ of the medium was adjusted to 7.2 to 7.4 prior to being reduced by the Hungate technique (2). For the preparation of media containing insoluble substrates, such as cellulose, the reduced medium was dispensed, under $80 \% \mathrm{~N}_{2}-20 \%$ $\mathrm{CO}_{2}$, in $10-\mathrm{ml}$ volumes into $60-\mathrm{ml}$ serum vials containing preweighed amounts of the substrate and was then autoclaved. Soluble substrates were filter sterilized and were injected by hypodermic syringe into the basal medium after the vials had been autoclaved and cooled. The isolated microorganism was maintained in basal medium supplemented with $2 \%(\mathrm{wt} / \mathrm{vol})$ cellobiose and $0.1 \%$ yeast extract (YE).

Isolation. A methanogenic cellulose-enrichment culture described by Khan (4) was used as the source of inoculum for isolation purposes. The inoculum was heated at $90^{\circ} \mathrm{C}$ for $15 \mathrm{~min}$ and was then serially diluted in basal medium. Prereduced cellobiose-agar slants, inside 160 -ml serum vials, supplemented with $0.1 \%$ (wt/vol) YE, were spread with a $0.1-\mathrm{ml}$ quantity of

\footnotetext{
† Issued as NRCC no. 19895.
}

each dilution. The inoculated agar slants were flushed with an $80 \% \mathrm{~N}_{2}-20 \% \mathrm{CO}_{2}$ gas mixture, sealed, and incubated at $35^{\circ} \mathrm{C}$. After $48 \mathrm{~h}$, an individual colony was picked and transferred to cellobiose-YE broth. The broth was heated at $90^{\circ} \mathrm{C}$ for $15 \mathrm{~min}$, serially diluted, and replated on cellobiose-YE agar. This procedure was repeated a total of five times.

Biochemical tests. Biochemical tests were carried out in basal medium containing $0.1 \% \mathrm{YE}$ and $2 \%$ of the selected substrate, by the procedures of Holdeman and Moore (1). The inoculated test vials were incubated at $35^{\circ} \mathrm{C}$. Since some of the substrates were insoluble, all liquid media were incubated with rotary shaking at $200 \mathrm{rpm}$. Test results were determined at $48 \mathrm{~h}$ and again after 7 days. All negative tests were held for 4 weeks. Analyses were made to determine gas volume, gas composition $\left(\mathrm{N}_{2}, \mathrm{H}_{2}\right.$, and $\left.\mathrm{CO}_{2}\right)$, and volatile acids (formic, acetic, propionic, etc.) by previously described methods (5). Analyses of alcohols and nonvolatile acids were performed as described by Holdeman and Moore (1). Control vials, without substrate, were inoculated to account for the growth due to the $0.1 \% \mathrm{YE}$ and for metabolic products introduced as part of the inoculum.

Photomicrographs and electron micrographs. For electron microscopy, a 24-h-old colony was picked from cellobiose-YE agar. After dilution in distilled water, the cells were placed in Formvar films and dialyzed overnight. The films were placed on carboncoated grids, shadowed with $\mathrm{Pd}-\mathrm{Au}$, and examined with a Siemens electron microscope, model 101. For electron micrographs of sporeforming cells, a 72 -h-old colony was picked.

Colonies grown on agar slants were placed on a black background, under incident light, and photographed with Polaroid $55 \mathrm{P} / \mathrm{N}$ panchromatic film. The negative was then contact printed.

Growth measurements. Growth in cellobiose-YE broth was measured by optical density $(650 \mathrm{~nm})$ in a Beckman spectrophotometer, model 25. Growth-temperature studies were performed at incubation tem- 


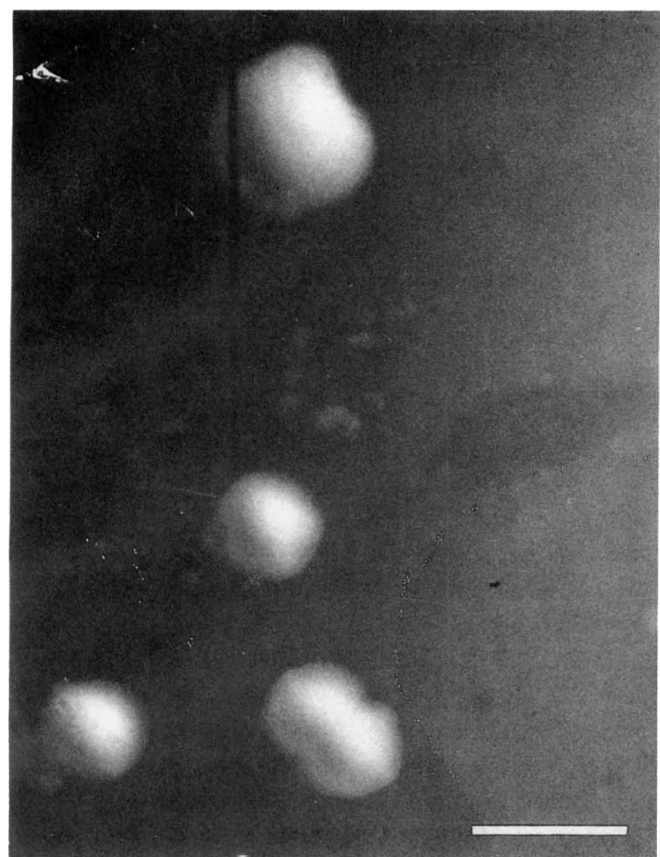

FIG. 1. Growth on cellobiose-YE agar. The bar represents $2 \mathrm{~mm}$.

peratures of 10 to $55^{\circ} \mathrm{C}$ in about $5^{\circ} \mathrm{C}$ increments. The $\mathrm{pH}$ tolerance of the isolated microorganism was determined at $35^{\circ} \mathrm{C}$ in cellobiose-YE broths by adjusting the $\mathrm{pH}$ from 4.5 to 10.0 in increments of approximately 0.3 $\mathrm{pH}$ unit.

DNA base composition. For determination of the deoxyribonucleic acid (DNA) base composition, the cells were grown in 1.5 liters of cellobiose-YE broth for $48 \mathrm{~h}$ and then harvested by centrifugation. The cells were washed once and then resuspended in 10 volumes of the lysing medium of Markov and Ivanov (7). To facilitate breakage, the cells were disrupted ultrasonically, in 20-s bursts, with a Bronwill Biosonik sonicator. Disruption was followed spectrophotomet- rically $(650 \mathrm{~nm})$ and was considered to be complete when repeated sonication failed to cause a further decrease in optical density. The DNA was purified by chromatography on hydroxyapatite columns (Bio-Rad Laboratories, DNA grade Bio-Gel HTP) by the method of Markov and Ivanov (7). The DNA base composition was determined by ultraviolet spectroscopy (11); Escherichia coli DNA (Calbiochem), with a guanineplus-cytosine content of $51 \mathrm{~mol} \%$, was used as a standard.

\section{RESULTS}

Isolation of the new microorganism was accomplished by repeated heating to $90^{\circ} \mathrm{C}$ for 15 min followed by serial dilution and plating on cellobiose-YE agar. Colonies reached maximum size after $48 \mathrm{~h}$ at $35^{\circ} \mathrm{C}$. These colonies were approximately 0.5 to $1.5 \mathrm{~mm}$ in diameter, white, convex, and circular with smooth margins (Fig. 1).

Single cells (Fig. 2) were straight, spindleshaped rods, approximately 0.6 by $3.0 \mu \mathrm{m}$. Spores, which were round and terminally located in the cells, were present in cultures 3 or more days old (Fig. 3). The cells were nonmotile, with no flagella visible in electron micrographs (Fig. 2). The isolate was gram negative, catalase negative, and not encapsulated. It was strictly anaerobic, requiring prereduced media for growth.

Table 1 lists the biochemical characteristics of the isolated strain, designated WM1. It was necessary to supplement the basal medium with $0.1 \% \mathrm{YE}$, as no growth was obtained in any of the substrates without it. This amount of YE was itself able to support a small amount of growth, which was accounted for in the test vials by running duplicate controls. The microorganism was unable to digest cellulose, but it could use cellobiose, as well as a wide variety of other carbohydrates. Of all the test substrates (1), only

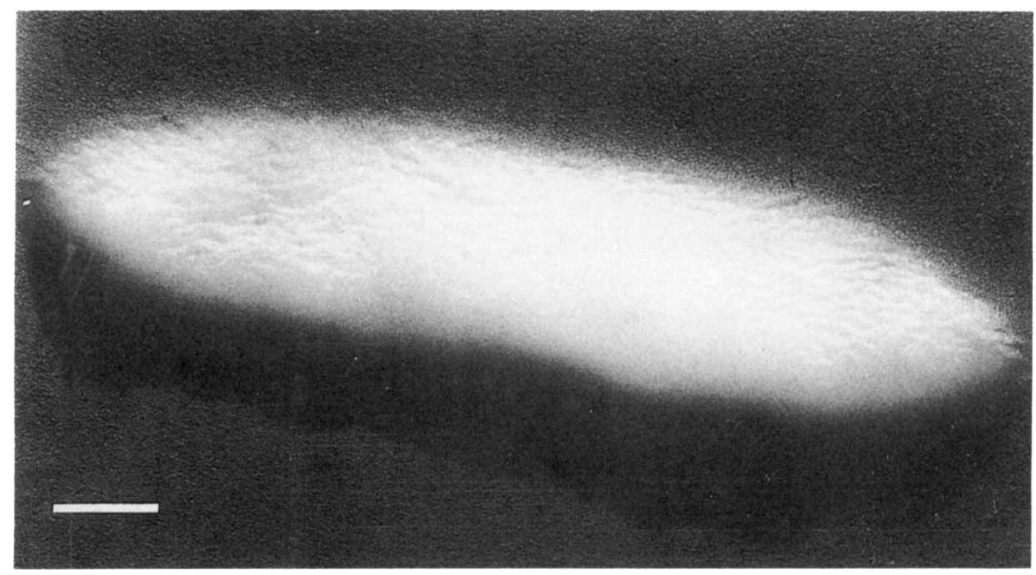

FIG. 2. Electron micrograph depicting the morphology of strain WM1. The bar represents $0.33 \mu \mathrm{m}$. 


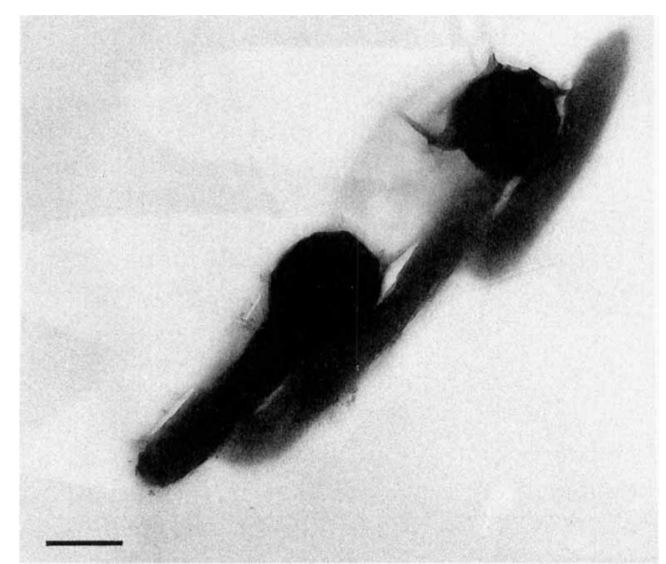

FIG. 3. Cell morphology of culture during early spore development. Mature spores were round and terminal and distended the cell walls. The bar represents $1.0 \mu \mathrm{m}$.

arabinose, casein, dulcitol, erythritol, inulin, lactic acid, peptone, sorbitol, starch, and urea failed to support growth. The metabolic products detected in cellobiose-YE broth after 7 days of incubation were acetic acid, hydrogen, carbon dioxide, ethanol, and traces of pyruvic and lactic acids.

The temperature range in which growth occurred was 17 to $43^{\circ} \mathrm{C}$, with maximum growth at about $37^{\circ} \mathrm{C}$. There was no growth at 15 or $45^{\circ} \mathrm{C}$. The $\mathrm{pH}$ tolerance of this microbe was between 6.0 and 8.8 , with maximum growth occurring at $\mathrm{pH} 7.4$.

The DNA base composition of strain WM1 was determined to be $28 \mathrm{~mol} \%$ guanine plus cytosine. This compares well with members of the genus Clostridium (3).

\section{DISCUSSION}

Strain WM1 is a sporeforming rod belonging to the family Bacillaceae. It is a strict anaerobe and does not reduce sulfate to sulfide. Accordingly, it belongs in the genus Clostridium. Furthermore, its spores are terminal, and it does not hydrolyze gelatin. This places the new isolate in group III of the classification of clostridia by Smith and Hobbs (10). However, the biochemical characteristics of strain WM1 do not match the biochemical profiles of any of the known species. The distinguishing feature of this microorganism is its ability to metabolize a wide range of sugars. Therefore, we propose the establishment of a new species of Clostridium, C. saccharolyticum, so named for its broad saccharolytic ability.

C. saccharolyticum was unable to degrade cellulose, even though it was isolated from a cellulolytic culture in which cellulose was the only added substrate. This indicates that $C$.
TABLE 1. Biochemical Characteristics of strain

\begin{tabular}{|c|c|c|}
\hline $\begin{array}{l}\text { Substrate or } \\
\text { medium }^{a}\end{array}$ & Growth $^{b}$ & Comments \\
\hline Adonitol & + & \\
\hline Amygdalin & + & \\
\hline Arabinose & - & \\
\hline $\begin{array}{l}\text { Cellobiose (no } \\
\text { resazurin) }\end{array}$ & + & $\begin{array}{l}\text { Acetylmethylcarbinol } \\
\text { and ammonia } \\
\text { produced }\end{array}$ \\
\hline Cellulose & - & \\
\hline Dulcitol & - & \\
\hline Esculin & + & $\begin{array}{l}\text { Positive esculin } \\
\text { hydrolysis }\end{array}$ \\
\hline Erythritol & - & \\
\hline Fructose & + & \\
\hline Galactose & + & \\
\hline Glucose & + & \\
\hline Glycerol & $w^{c}$ & \\
\hline Inositol & + & \\
\hline Inulin & - & \\
\hline Lactose & + & \\
\hline Maltose & + & \\
\hline Mannitol & + & \\
\hline Mannose & + & \\
\hline Melezitose & + & \\
\hline Melibiose & + & \\
\hline Raffinose & + & \\
\hline Rhamnose & + & \\
\hline Ribose & + & \\
\hline Salicin & + & \\
\hline Sorbitol & - & \\
\hline Sorbose & + & \\
\hline Starch & - & \\
\hline Sucrose & + & \\
\hline Trehalose & + & \\
\hline Xylose & + & \\
\hline Casamino Acids & $\mathrm{w}^{c}$ & \\
\hline Casein & - & \\
\hline Lactate & - & \\
\hline $\begin{array}{l}\text { Chopped meat } \\
\text { broth }\end{array}$ & + & \\
\hline Milk & + & Curd formation \\
\hline Peptone & - & \\
\hline Pyruvate & + & \\
\hline Urea & - & Urease negative \\
\hline Yeast extract & + & \\
\hline Cellobiose agar & + & Catalase negative \\
\hline $\begin{array}{l}\text { Indole-nitrate } \\
\text { broth }\end{array}$ & + & $\begin{array}{l}\text { Indole produced, } \\
\text { nitrate not reduced }\end{array}$ \\
\hline Thiogel & + & Gelatin not liquefied \\
\hline $\begin{array}{l}\text { Sulfate-reduction } \\
\text { medium }\end{array}$ & + & Sulfate not reduced \\
\hline
\end{tabular}

${ }^{a}$ All media prepared as described by Holdeman and Moore (1) and supplemented with $0.1 \%$ YE.

${ }^{b}$ No growth $(-)$ or growth $(+)$ determined by turbidity and acid and gas production.

c Weakly positive.

saccharolyticum depended on the cellulolytic microorganism(s) for the production of sugars as well as for the production of a growth factor replaceable by $0.1 \% \mathrm{YE}$. 
C. saccharolyticum differed from other acetate-forming, mesophilic anaerobes so far isolated from municipal sewage sludge. The microorganism AC1 isolated from a methanogenic culture (9) closely resembles $C$. saccharolyticum in being a spindle-shaped, gram-negative rod and in requiring $\mathrm{YE}$ for growth and the production of acetic acid, hydrogen, and carbon dioxide. However, AC1 differs from C. saccharolyticum, as it is motile and does not produce spores. The acetate-producing clostridium isolated from sewage sludge by Ohwaki and Hungate (8), which is similar to $C$. aceticum (12), also differs from $C$. saccharolyticum in that it converts hydrogen and carbon dioxide to acetic acid.

A formal description of this species follows:

Clostridium saccharolyticum sp. nov. (Gr. noun sacchar sugar; Gr. adj. lyticus dissolving; M.L. adj. saccharolyticum sugar-dissolving).

Morphology: Straight, spindle-shaped rods, 0.5 to $0.7 \mu \mathrm{m}$ by $3.0 \mu \mathrm{m}$. Spores are round and terminal and cause cell swelling. Nonmotile. Gram negative.

Colony characteristics. White, circular, convex, smooth margins, 0.5 to $1.5 \mathrm{~mm}$ in diameter.

Nutrition: Saccharolytic, capable of fermenting adonitol, amygdalin, cellobiose, esculin, fructose, galactose, glucose, glycerol, inositol, lactose, maltose, mannitol, mannose, melezitose, melibiose, raffinose, rhamnose, ribose, salicin, sorbose, sucrose, trehalose, and xylose. It cannot use arabinose, cellulose, dulcitol, erythritol, inulin, sorbitol, or starch. Requires a growth factor provided by $0.1 \%$ yeast extract.

Fermentation products: Produces acetic acid, hydrogen, carbon dioxide, ethanol, and traces of pyruvic and lactic acids from cellobiose.

Biochemical reactions: Gelatin not liquefied; sulfate and nitrate not reduced; produces acetylmethylcarbinol, ammonia, and indole; catalase and urease negative.

Temperature relationships: Temperature for optimal growth is $37^{\circ} \mathrm{C}$; growth range, 17 to $43^{\circ} \mathrm{C}$.

$\mathrm{pH}$ relationship: $\mathrm{pH}$ for optimal growth is 7.4 ; growth range, $\mathrm{pH} 6.0$ to 8.8 .

DNA base composition: 28 mol\% guanine plus cytosine.
Source: Methanogenic cellulose-enrichment culture from sewage sludge.

Type strain: WM1. This strain has been deposited in the National Research Council of Canada culture collection under the accession number NRC 2533.

\section{ACKNOWLEDGMENTS}

We appreciate the assistance of J. R. Colvin and L. C. Sowden with the electron microscopy and $H$. Turner in preparation of the photomicrographs.

\section{REPRINT REQUESTS}

Address reprint requests to: Dr. W. D. Murray, Division of Biological Sciences, National Research Council of Canada. Ottawa, Canada K1A 0R6.

\section{LITERATURE CITED}

1. Holdeman, L. V., and W. E. C. Moore (ed.). 1973. Anaerobe laboratory manual, 2nd ed. Anaerobe Laboratory, Virginia Polytechnic and State University, Blacksburg.

2. Hungate, R. E. 1950. The anaerobic mesophilic cellulolytic bacteria. Bacteriol. Rev. 14:1-49.

3. Johnson, J. L., and B. S. Francis. 1975. Taxonomy of the clostridia: ribosomal ribonucleic acid homologies among the species. J. Gen. Microbiol. 88:229-244.

4. Khan, A. W. 1977. Anaerobic degradation of cellulose by mixed culture. Can. J. Microbiol. 23:1700-1705.

5. Khan, A. W., and T. M. Trottier. 1978. Effect of sulfurcontaining compounds on anaerobic degradation of cellulose to methane by mixed cultures obtained from sewage sludge. Appl. Environ. Microbiol. 35:1027--1034.

6. Khan, A. W., T. M. Trottier, G. B. Patel, and S. M. Martin. 1979. Nutrient requirement for the degradation of cellulose to methane by a mixed population of anaerobes. J. Gen. Microbiol. 112:365-372.

7. Markov, G. C., and I. G. Ivanov. 1974. Hydroxyapatite column chromatography in procedures for isolation of purified DNA. Anal. Biochem. 59:555-563.

8. Ohwaki, K., and R. E. Hungate. 1977. Hydrogen utilization by clostridia in sewage sludge. Appl. Environ. Microbiol. 33:1270-1274

9. Patel, G. B., and L. A. Roth. 1978. Acetic acid and hydrogen metabolism during coculture of an acetic acid producing bacterium with methanogenic bacteria. Can. J. Microbiol. 24:1007-1010.

10. Smith, L. D. S., and G. Hobbs. 1974. Clostridium. p. 551572. In R. E. Buchanan and N. E. Gibbons (ed.), Bergey's manual of determinative bacteriology. The Williams \& Wilkins Co., Baltimore.

11. Ulitzer, S. 1972. Rapid determination of DNA base composition by ultraviolet spectroscopy. Biochim. Biophys. Acta 272:1-11.

12. Wieringa, K. T. 1940 . The formation of acetic acid from carbon dioxide and hydrogen by anaerobic sporeforming bacteria. Antonie van Leeuwenhoek J. Microbiol. Serol. 6:251-262. 